\title{
ANALISIS METODE BAGI HASIL PRODUK TABUNGAN INVESTA CENDEKIA PADA BANK SYARIAH MANDIRI KCP KATAMSO YOGYAKARTA TAHUN 2011
}

\author{
Retno Intansari Rahmawati \\ Alumni Program Studi Ekonomi Islam, Fakultas Ilmu Agama Islam, Universitas Islam Indonesia \\ Guru di Foundation of Saengtham Wittaya School Trang Thailand \\ e-mail: r.intansari89@gmail.com
}

\begin{abstract}
Abstrak
Kajian ini menganalisis kesesuaian Produk Tabungan Investa Cendekia, salah satu produk keuangan pada Bank Syariah Mandiri Cabang Katamso Yogyakarta, terhadap ketentuan syariah. Ketentuan syariah yang dimaksud meliputi implementasi kontrak, proses penentuan rasio bagi hasil keuntungan, dan mekanisme operasional produk tersebut. Metode yang digunakan mencakup observasi, dokumentasi, dan wawancara dengan supervisor dan costumer service yang mengetahui produk keuangan ini. Hasilnya menunjukkan bahwa akad yang digunakan pada Produk Tabungan Investa Cendekia adalah mudhârabahmuthlaqah, the customer as shâhibul mâl (pemilik modal) dan bank sebagai mudhârib (pengelola). Keuntungan bagi hasil pada produk ini dihitung berdasarkan saldo rata-rata harian dan akan dibukukan ke rekening tabungan.Operasional produk ini sudah sesuai dengan prinsip-prinsip syariah sebagaimana diatur dalam Fatwa DSN-MUI.
\end{abstract}

Kata Kunci: tabungan, investasi, bagi hasil, bancassurance, Tabungan Investa Cendekia

\begin{abstract}
This study aimed to analyses the suitability of Tabungan Investa Cendekia, a product of Bank Syariah Mandiri, Katamso Branch of Yogyakarta, to Islamic principles. The scoop of the Islamic principles aimed in this study was the implementation of the contract, the process of determining the profit sharing ratio, and operational mechanisms of the product. The methods used was observation, documentation, and interviews with the supervisor and customer service who were the person in charge of the product. The results suggested that the akad (agreement) used in Tabungan Investa Cendekia wasmudhârabahmuthlaqahin which customer acted as shâhibul mâl (owners of capital) and bank acted as mudhârib (manager). Profit sharing in the product was calculated based on the average daily balance and booked into saving account. Operational mechanism of the product was also compliance with Islamic principles regulated by a fatwa of Scholar Council of Indonesia.
\end{abstract}

Keywords: savings, investment, profit sharing, bancassurance, Tabungan Investa Cendekia 


\section{PENDAHULUAN}

\section{A. Latar Belakang}

Pertumbuhan ekonomi suatu negara tidak terlepas dari peran sektor perbankan. Awalnya bank hanya berperan sebagai tempat menyimpan uang agar aman dari pencurian ataupun terjadinya musibah baik alam maupun karena ulah tangan manusia yang mungkin terjadi. Seiring berjalannya waktu bank berkembang selain sebagai tempat menabung, juga sebagai tempat meminjam uang untuk modal usaha ataupun untuk memenuhi kebutuhan konsumtif manusia.Bank juga berperan sebagai tempat investasi masa depan bagi nasabahnyaserta memberikan jasa pengiriman uang. ${ }^{1}$ Sejak lama masyarakat mengenal bank hanya sebagai sebuah institusi yang dapat memberikan keuntungan lebih ketika menyimpan uang di bank, yaitu berupa bunga (interest).

Sebagian besar masyarakat menganggap bahwa bunga bank yang mereka peroleh adalah hal yang wajar dan patut mereka peroleh, ketika mereka menyimpan uang di bank. Tanpa pernah mereka sadari bahwa sebenarnya bunga bank termasuk praktek kegiatan ekonomi rentenir, yang selanjutnya dipraktekkan oleh dunia perbankan dengan lebih profesional. Memperoleh imbalan bunga dengan menyimpan uang di bank sama saja dengan menggandakan uang, padahal uang dalam tinjauan ajaran Islam hanya berfungsi sebagai alat tukar terhadap aktivitas transaksi yang dilakukan oleh masyarakat bukan sebagai alat komoditi. ${ }^{2}$ Saat ini ada cara lain yang membuat masyarakat tetap bisa merasa aman menyimpan uang di bank, setelah berdirinya bank syariah. Masyarakat dapat menikmati bagi hasil dari uang yang mereka simpan di bank syariah. Dimana bagi hasil tidak sama dengan bunga.

Kecenderungan masyarakat menggunakan sistem bunga (interest) lebih bertujuan untuk mengoptimalkan pemenuhan kepentingan pribadi, sehingga kurang mempertimbangkan dampak sosial yang ditimbulkannya. Berbeda dengan sistem bagi hasil, sistem ini berorientasi pemenuhan kemaslahatan hidup umat manusia. Adapun perbedaan bunga dan bagi hasil dapat dijelaskan lebih jauh pada tabel berikut: ${ }^{3}$

\section{Tabel 11 Perbedaan antara Bunga dan Bagi-hasil}

\begin{tabular}{|l|l|}
\hline \multicolumn{1}{|c|}{ Bunga } & \multicolumn{1}{|c|}{ Bagi-hasil } \\
\hline $\begin{array}{l}\text { Penentuan bunga dibuat pada waktu akad } \\
\text { dengan asumsi harus selalu untung. }\end{array}$ & $\begin{array}{l}\text { Penentuan besarnya rasio bagi-hasil dibuat pada } \\
\text { waktu akad dengan berpedoman pada } \\
\text { kemungkinan untung rugi. }\end{array}$ \\
\hline
\end{tabular}

${ }^{1}$ Adiwarman A. Karim (2003),Bank Islam: Analisis Fiqih dan Keuangan, cet.1 (Jakarta: IIIT Indonesia), p. 22.

${ }^{2}$ Muhammad (2006), Teknik Perbitungan Bagi Hasil dan Profit Margin pada Bank Syariah, cet. 3 (Yogyakarta: UII Press), p. 12.

${ }^{3}$ Heri Sudarsono (2008),Bank dan Lembaga Keuangan Syariah: Deskripsi dan Ilustrasi, Cet. I. (Yogyakarta: Ekonisia), pp. 20-21. 


\begin{tabular}{|l|l|}
\hline $\begin{array}{l}\text { Besarnya prosentase berdasarkan pada } \\
\text { jumlah modal yang dipinjamkan. }\end{array}$ & $\begin{array}{l}\text { Besarnya rasio bagi-hasil berdasarkan pada } \\
\text { jumlah keuntungan yang diperoleh. }\end{array}$ \\
\hline $\begin{array}{l}\text { Pembayaran bunga tetap seperti dijanjikan } \\
\text { tanpa pertimbangan apakah proyek yang } \\
\text { dijalankan oleh pihak nasabah untung atau } \\
\text { rugi. }\end{array}$ & $\begin{array}{l}\text { Bagi hasil bergantung pada keuntungan proyek } \\
\text { yang dijalankan. Bila usaha merugi, kerugian } \\
\text { akan ditanggung bersama oleh kedua belah } \\
\text { pihak. }\end{array}$ \\
\hline $\begin{array}{l}\text { Jumlah pembayaran bunga tidak meningkat, } \\
\text { sekalipun jumlah keuntungan berlipat. }\end{array}$ & $\begin{array}{l}\text { Jumlah pembagian laba meningkat sesuai } \\
\text { dengan peningkatan jumlah pendapatan. }\end{array}$ \\
\hline $\begin{array}{l}\text { Eksistensi bunga diragukan oleh semua } \\
\text { agama termasuk agama Islam }\end{array}$ & tidak ada yang meragukan keabsahan bagi-hasil. \\
\hline
\end{tabular}

Sumber: Heri Sudarsono (2008), Bank dan Lembaga Keuangan Syariah, p. 20-21.

Prinsip bagi hasil (mudharabah) dalam PP No. 72 tahun 1992 tentang Bank, menjadi dasar hukum yuridis normatif dalam pengoperasian perbankan syariah di Indonesia yang menandai dimulainya era sistem perbankan ganda (dual banking system) di Indonesia. Selanjutnya pada tahun 1998 dikeluarkan UU No 10 tahun 1998 sebagai amandemen dari Undang-Undang No 7 Tahun 1992 tentang perbankan yang memberikan landasan hukum yang lebih kuat bagi keberadaan sistem perbakan syariah.

Pada tahun 1999 dikeluarkan Undang-Undang No 23 Tahun 1999 tentang Bank Indonesia yang memberikan kewenangan kepada Bank Indonesia untuk dapat menjalankan tugasnya berdasarkan prinsip syariah. Hingga saat ini dunia perbankan syariah di Indonesia masih terus menunjukkan eksistensi kinerjanya setelah dikeluarkannya UU No 21 Tahun 2008 tentang perbankan syariah yang merupakan spesifikasi undang-undang tersendiri dari UU No 10 Tahun 1998. Berdasarkan laporan Bank Indonesia, aset total perbankan syariah pada Agustus 2011 mencapai Rp 120 triliun. Aset bank umum syariah dan unit usaha syariah mencapai Rp 116 triliun. Sedangkan Bank Pembiayaan Rakyat Syariah mencapai Rp 3,7 triliun. ${ }^{4}$

Salah satu bank syariah yang menunjukkan eksistensinya di dunia perbankan syariah Indonesia adalah Bank Syariah Mandiri yang berdiri dan resmi beroperasi pada tanggal 1 November 1999. Pada dasarnya produk-produk yang ditawarkan oleh perbankan syariah dapat digolongkan menjadi 3 bagian, yaituproduk penghimpunan dana (funding); produk penyaluran dana (financing); dan produk jasa (service). ${ }^{5}$

Salah satu produk penghimpunan dana (funding) yang ditawarkan oleh bank Syariah Mandiri adalah tabungan Investa Cendekia. Tabungan Investa Cendekia adalah tabungan investasi berjangka yang ditawarkan untuk perencanaan kebutuhan dana

${ }^{4}$ http://zonaekis.com/pertumbuhan-perbankan-syariah-belum-selesaikan-masalah-ekonomi, diakses pada 3 Oktober 2011.

${ }^{5}$ Adiwarman A. Karim (2010),Bank Islam Analisis Fiqih dan Keuangan, Cet.7 (Jakarta: Raja Grafindo Persada), p. 97. 
pendidikan disertai dengan asuransi jiwa yang secara otomatis diperoleh nasabah sejak dibukanya Tabungan BSM Investa Cendekia. Walaupun ada fitur tambahan berupa asuransi, akan tetapi Tabungan BSM Investa Cendekia tidak merubah fitur lembaga keuangan Islam yaitu bagi hasil. ${ }^{6}$

Berdasarkan data BPS, kenaikan biaya pendidikan pada Juli 2009 dibanding tahun 2000 mencapai 227\%. Pada tahun 2000 indeksharga biaya pendidikan berada di level 100, sedangkan pada tahun 2009 mencapai level 327. Inflasi di Indonesia dalam waktu 10 tahun terakhir berkisar 12-15\%. Sementara kenaikan biaya pendidikan setiap tahunnya mencapai 20\%.7 Hal ini berarti kenaikan biaya pendidikan lebih tinggi daripada inflasi setiap tahunnya.Tingginya biaya pendidikan di Indonesia yang kian tahun kian meningkat ini memang akan paling terasa bagi para mahasiswa dari kalangan ekonomi menengah ke bawah. Setiap tahun ajaran baru, orangtua mengulangi ritual yang harus dijalani setiap tahun, seperti menyiapkan sekolah untuk anak-anaknya dengan segala masalahnya.

Produk Tabungan BSM Investa Cendekia merupakan tabungan berjangka untuk perencanaan pendidikan putra-putri di masa depan yang memiliki fitur tambahan berupa proteksi asuransi.Hal ini menjadi topik menarik untuk diteliti terutama dikaitkan dengan bagaimana sistem bagi hasil diterapkan pada produk Tabungan BSM Investa Cendekia sehingga dapat membantu para orang tua untuk mengatasi kesulitan biaya pendidikan. Oleh karena itu, penelitian ini menanalisis sistem bagi hasil produk tabungan Investa Cendekia pada Bank Syariah Mandiri KCP Katamso Yogyakarta berdasarkan data pada tahun 2011.

\section{TINJAUAN PUSTAKA DAN LANDASAN TEORI}

\section{A. Tinjauan Pustaka}

Pembahasan tentang analisis bagi hasil produk tabungan pada lembaga keuangan syariah telah banyak dilakukan, hal ini terbukti dengan adanya penelitian dan karya lepas yang secara esensi hampir menyamai dengan penelitian kali ini, tetapi terdapat berbagai macam perbedaan bentuk analisis dan pembahasan yang dipaparkan. Sejumlah penelitian yang telah dilakukan dijelaskan dalam pembahasanberikut. Dewi Rohma Fadhila meneliti tentang pengaruh tingkat bagi hasil dan suku bunga bank konvensional terhadap simpanan mudharabahdengan studi kasus bank syariah mandiri. Menggunakan metode alat analisis regresi linier, penelitian menyimpulkan bahwa variabel tingkat keuntungan bagi hasil tidak berpengaruh signifikan terhadap simpanan

${ }^{6}$ http://www.syariahmandiri.co.id/category/info-perusahaan/profil-perusahaan diakses pada 3 Oktober 2011.

${ }^{7}$ http://netsains.com/2011/09/ironi-dunia-pendidikan/, diakses pada 14 Februari 2012. 
mudharabah bank syariah mandiri, sedangkan variabel suku bunga berpengaruh negatif dan signifikan terhadap simpanan mudharabah di BSM. ${ }^{8}$

Umi Fauziyah menganalisis metode perhitungan bagi hasil pada pembiayaan mudharabah berdasarkan fatwa Dewan Syariah Nasional (DSN) di BMT KHONSA Cilacap. Penelitian dilakukan dengan analisis kualitatif menggunakan metode induktif dan berkesimpulan bahwa metode revenue sharing lebih menguntungkan daripada profit sharing. Hal ini ditunjukkan dengan Ho ditolak karena $\mathrm{T}$ hitung $=10,106>\mathrm{T}$ tabel $=$ 1,669.Berdasarkan hal tersebut maka BMT KHONSA Cilacap menggunakan metode revenue sharing. ${ }^{9}$

Fatahullah menelitiimplementasi prinsip bagi hasil dan resiko di perbankan syariah cabang Mataram. Penelitian ini dilakukan dengan pendekatan doktrinal atau normatif, yang memandang hukum sebagai seperangkat aturan atau kaidah yang bersifat normatif. Penelitian menyimpulkan bahwa pelaksanaan penghimpunan dana dengan menggunakan prinsip bagi hasil di perbankan syariah Mataram dilakukan dengan prinsip wadiah dan mudharabah. Ada beberapa kendala operasional yang dihadapi oleh perbankan syariah Mataram dalam implementasi pembiayaan bagi hasil seperti kendala Sumber Daya Manusia Insani, manajemen perbankan syariah, jaringan kantor yang masih terbatas dan masih lemahnya regulasi pemerintah terhadap perbankan syariah. ${ }^{10}$

Bank Indonesia dalam salah satu artikel edukasi perbankannyamenjelaskan kepada masyarakat bagaimana perbankan syariah menerapkan prinsip syariah dalam setiap operasinya, yaitu dengan bagi hasil antara nasabah dan bank syariah. Nasabah menyimpan uang di bank syariah dan diperlakukan sebagai pemilik dana yang melakukan investasi pada bank syariah. Bank syariah kemudian akan mengelola dana masyarakat tersebut, melalui investasi ke sektor-sektor produktif yang menghasilkan keuntungan. Di akhir bulan keuntungan tersebut akan dibagihasilkan sesuai kesepakatan. $^{11}$

Dalam artikel edukasi perbankan lainnya, Bank Indonesia juga memberikan penjelasan kepada masyarakat tentang bagaimana menghitung nisbah bagi hasil. Proporsi bagi hasil antara nasabah dan bank syariah. Misalnya, jika customer service bank

${ }^{8}$ Dewi Rohma Fadhila (2004), "Pengaruh Tingkat Bagi Hasil Dan Suku Bunga Terhadap Simpanan Mudharabah (Studi Kasus Bank Syariah Mandiri) Periode Januari 2001-Juni 2003", Skripsi Fakultas Ekonomi Universitas Islam Indonesia. Tidak diterbitkan.

${ }^{9}$ Umi Fauziyah, (2006), "Analisis Metode Perhitungan Bagi Hasil pada Pembiayaan Mudharabah Berdasarkan Fatwa Dewan Syariah Nasional (DSN) di BMT KHONSA Cilacap”. Skripsi STAIN Surakarta. Tidak diterbitkan.

${ }^{10}$ Fatahullah (2008), "Implementasi Prinsip Bagi Hasil dan Risiko di Perbankan Syariah (Studi di Perbankan Syariah Cabang Mataram)". Tesis Program Magister Ilmu Hukum Universitas Diponegoro Semarang. Tidak diterbitkan.

${ }^{11}$ Bank Indonesia (2009), "Mari Berbagi Hasil Bersama iB”.Artikel edukasi perbankan diakses dari http://www.bi.go.id/web/id/Perbankan/Edukasi+Perbankan/Mari Berbagi Hasil.htmpada 1 November 2011 
syariah menawarkan nisbah bagi hasil Tabungan iB sebesar 65:35. Itu artinya nasabah bank syariah akan memperoleh bagi hasil sebesar 65\% dari return investasi yang dihasilkan oleh bank syariah melalui pengelolaan dana-dana masyarakat di sektor riil. Sementara itu bank syariah akan mendapatkan porsi bagi hasil sebesar 35\%. ${ }^{12}$

Uraian terkait penelitian-penelitian diatas menunjukkan perbedaan pada penelitian ini.Penelitian sebelumnya lebih banyak terfokus pada manajemen pengelolaan bagi hasil dan implementasinya pada produk pembiayaan yang ditawarkan oleh lembaga keuangan syariah, sedangkan penelitian ini mencoba untuk fokus menggali informasi lebih dalam tentang sistem bagi hasil pada produk tabungan investa cendekia di Bank Syariah Mandiri dengan menggunakan informasi yang telah ada di dalam penelitian sebelumnya dengan menggunakan pendekatan kualitatif.

\section{B. Landasan Teori}

1. Sistem Bagi Hasil

Bagi hasil menurut terminologi asing (bahasa Inggris) dikenal dengan profit sharing dalam kamus ekonomi di artikan sebagai laba. Secara definisi profit sharing diartikan sebagai distribusi beberapa bagian dari laba kepada para pegawai dari suatu perusahaan. ${ }^{13}$ Pendapatan bagi hasil ini pada lembaga keuangan syariah berlaku untuk produk penghimpunan dana dan penyertaan modal. Baik penyertaan menyeluruh maupun sebagian atau bentuk korporasi (kerjasama). Keuntungan yang dibagi hasilkan harus dibagi secara proporsional antara shâhibul mâl dengan mudhârib sesuai dengan proporsi yang disepakati ketika akad. Dalam sistem ekonomi Islam, tingkat bunga yang dibayarkan bank kepada nasabah diganti dengan persentase atau porsi bagi hasil dan tingkat bunga yang diterima oleh bank (dari debitur) akan diganti dengan persentase bagi hasil.

Sistem bagi hasil ini adalah suatu sistem yang meliputi tata cara pembagian hasil usaha antara penyedia dana dengan pengelola dana. Pembagian hasil usaha ini dapat terjadi antara bank dengan penyimpan dana. Bentuk produk yang berdasarkan prinsip ini adalah Mudharabah dan Musyarakah. Lebih jauh prinsip mudharabah dapat dipergunakan sebagai dasar baik untuk produk pendanaan (tabungan dan deposito) maupun pembiayaan, sementara musyarakah lebih banyak untuk pembiayaan. ${ }^{14}$

Perkembangan lembaga keuangan syariah dengan berbagai instrumen yang ada menimbulkan optimisme akan perubahan sikap masyarakat terhadap keberadaan riba. Karena dampak daripada riba di tengah-tengah masyarakat tidak saja berpengaruh pada

\footnotetext{
${ }^{12}$ Bank Indonesia (2009), “Menghitung Bagi Hasil iB”.Artikel edukasi perbankan diakses dari http://www.bi.go.id/web/id/Perbankan/Edukasi+Perbankan/Menghitung Bagi Hasil iB.htmpada 1 November 2011.

${ }^{13}$ Muhammad. (2001),Tehnik Perhitungan Bagi Hasil di Bank Syariah(Yogyakarta: UII Press), p. 22.

${ }^{14}$ M. Syafi'i Antonio, et.al. (2008),Bank Syari'ah(Yogyakarta: Ekonisia), p. 18.
} 
kehidupan perekonomian tetapi dalam seluruh aspek kehidupan manusia. ${ }^{15}$ Riba merupakan salah satu bentuk penjajahan, karena riba dapat menimbulkan permusuhan antara sesama manusia, adanya riba menjadikan gap yang dalam sehingga yang kaya semakin kaya dan miskin tambah melarat. Riba pada nyatanya adalah pencuri, karena uang tidak melahirkan uang. ${ }^{16}$ Uang hanya sebatas alat tukar bukan barang komoditi.

2. Investasi Syariah

Investasi pada umumnya merupakan suatu istilah dengan beberapa pengertian yang berhubungan dengan keuangan dan ekonomi, to use (money) make more money out of something that expected to increase in value. Istilah tersebut berkaitan dengan akumulasi suatu bentuk aktiva dengan suatu harapan mendapatkan keuntungan di masa depan. Terkadang, investasi disebut sebagai penanaman modal. Artinya, investasi dapat diartikan sebagai pengeluaran yang ditujukan untuk meningkatkan atau mempertahankan stok barang modal. ${ }^{17}$

Namun berbeda dengan pengertian investasi pada umumnya, investasi dalam Islam pada dasarnya adalah bentuk aktif dari ekonomi syariah. Dalam Islam setiap harta ada zakatnya. Jika harta tersebut didiamkan, maka lambat laun akan termakan oleh zakatnya. Salah satu hikmah zakat ini adalah mendorong umat Islam untuk menginvestasikan hartanya agar bertambah. Jadi investasi bukan hanya tentang berapa keuntungan materi yang bisa didapatkan melalui aktivitas investasi, tetapi terdapat beberapa faktor yang mendominasi investasi dalam Islam, antara lain: ${ }^{18}$

> Akibat implementasi mekanisme zakat maka aset produktif yang dimiliki seseorang pada jumlah tertentu akan selalu dikenakan zakat, sehingga hal ini akan mendorong pemiliknya untuk mengelolanya melalui investasi.

> Aktifitas investasi dilakukan lebih didasarkan pada motif sosial yaitu membantu sebagian masyarakat yang tidak memiliki modal namun memiliki kemampuan berupa keahlian (skill) dalam menjalankan usaha, baik dilakukan dengan berserikat (musyarakah) maupun dengan berbagi hasil (mudharabah).

Bila hal ini dilakukan, maka golongan masyarakat yang aktif melakukan aktifitas investasi adalah golongan masyarakat muzakki. Golongan masyarakat ini memiliki potensi melakukan investasi akibat sumber daya ekonominya berlebih setelah memenuhi kebutuhan dasar dan kebutuhan untuk berjaga-jaga. Investasi ini tentu akumulasi dan perannya dalam perekonomian secara makro sangat besar. ${ }^{19}$

\section{Bancassurance}

\footnotetext{
${ }^{15}$ Heri Sudarsono (2008), Bank dan Lembaga Keuangan Syariah., hal. 21.

${ }^{16}$ Murtadha Muthahhari (1995), Pandangan Islam Tentang Asuransi dan Riba, (Bandung: Pustaka Hidayah), p.3.

${ }^{17}$ Abdul Aziz (2010), Manajemen Investasi Syariah, Cet.I (Bandung: ALFABETA), p.29.

${ }^{18}$ ibid,p.31.

${ }^{19}$ ibid. p.32.
} 
Saat ini perbankan sudah memiliki banyak produk yang dikenal masyarakat seperti pembiayaan, tabungan, deposito dan kartu kredit. Namun perbankan harus siap menghadapi risiko seperti kredit macet, baik karena bangkrutnya perusahaan yang meminjam maupun karena peminjamnya meninggal dunia. Oleh karena itu untuk meminimalisasi risiko tersebut, diperlukan perlindungan asuransi. Produk bancassurance memberi perlindungan terhadap risiko semacam ini. Selain berfungsi sebagai proteksi, bancassurance juga menumbuhkan sinergi antara lembaga keuangan dan asuransi. Bancassurance merupakan fitur yang menraik dan menguntungkan kegiatan bisnis perbankan maupun perusahaan asuransi.

Seiring berkembangnya sektor perbankan Indonesia, kini telah hadir inovasi pada sektor jasa keuangan, yaitu berkembangnya bancassurance. Istilah bancassurance berasal dari bahasa Perancis yang merupakan tempat lahirnya produk dan jasa bancassurance. Produk ini pertama kali diperkenalkan pada tahun 1970-an, namun baru dipasarkan secara efektif di negara tersebut pada tahun $1980 .{ }^{20} \mathrm{Pada}$ prinsipnya, bancassurance merupakan sistem penjualan produk asuransi melalui saluran distribusi bank. Dengan demikian, terjadi kemitraan antara pihak perusahaan asuransi dan bank dalam produk bancassurance. Namun istilah bancassurance bukan hanya menunjuk secara khusus pada sistem distribusinya saja, akan tetapi melibatkan aspek legal, fiskal dan budaya yang membentuk kesatuan integral konsep bancassurance. ${ }^{21}$

\section{METODE PENELITIAN}

\section{A. Jenis dan Lokasi Penelitian}

Penelitian ini adalah penelitian lapangan (field research) yang dapat disebut sebagai penelitian empiris. Penelitian ini dilakukan secara intensif, terperinci dan mendalam terhadap suatu objek tertentu dengan mempelajari sebagai suatu kasus dengan maksud untuk mecari kajian data empirik yang ditemukan dilapangan untuk kemudian dianalisis secara deskriptif dengan rujukan bahan pustaka. ${ }^{22}$ Adapun Penelitian ini dilakukan di Bank Syariah Mandiri KCP Katamso, yang berlokasi di Jl. Brigjen Katamso No. 160, Keparakan, Mergangsan, Yogyakarta.

\section{B. Sifat Penelitian}

Penelitian ini bersifat deskriptif kualitatif, yaitu menggunakan data yang dapat menggambarkan realitas aplikasi sistem bagi hasil pada produk tabungan investa cendekia BSM, kemudian diformulasikan dan dianalisis atau melakukan pengukuran melalui teori-teori yang relevan dengan masalah yang diangkat.

\footnotetext{
${ }^{20}$ Ketut Sendra (2007), Bancassurance $=$ Bank + Asuransi, Cet. 1 (Jakarta: PPM) p. 1.

${ }^{21}$ ibid.

${ }^{22}$ Supardi (2005), Metodologi Penelitian Ekonomi dan Bisnis (Yogyakarta: UII Press),p. 34.
} 


\section{Pendekatan Penelitian}

Penelitian ini menggunakan pendekatan yuridis normatif yaitucara mendekati masalah yang diteliti, dengan permasalahan yang akan dibahas dengan melihat apakah benar atau tidak berdasarkan aturan-aturan yang berlaku.

\section{Sumber Data}

Data yang digunakan adalah data primer dan data sekunder. Data primer berupa pengumpulan data yang dilakukan secara langsung pada lokasi penelitian dalam bentuk wawancara kepada pihak bank yang berwenang menjelaskan aplikasi produk investa cendekia dan pihak yang mengelola dana tabungan investa cendekia. Sedangkan data sekunder adalah pengumpulan data yang dilakukan melalui studi bahan-bahan kepustakaan yang perlu untuk mendukung data primer, merupakan dokumentasi baik dalam bentuk buku tentang bagi hasil yang dikarang oleh beberapa ahli, jurnal ekonomi Islam, Fatwa DSN-MUI, internet dan maupun penelitian yang dilakukan orang lain dalam hal bagi hasil.

\section{E. Teknik Pengumpulan Data}

Penelitian ini menggunakan wawancara mendalam yang mendasarkan pada kriteria teknis wawancara. Metode wawancara yang digunakan adalah wawancara bebas terpimpin, yakni pewawancara hanya membawa pedoman yang merupakan garis besar tentang hal-hal yang akan ditanyakan. Sementara ini, informan primer yang akan diwawancarai adalah Supervisor dan Customer Service Bank Syariah Mandiri KCP Katamso Yogyakarta. Selain wawancara, metode lain yang digunakan yaitu dengan cara dokumentasi yang berupa dokumen-dokumen dari Bank Syariah Mandiri KCP Katamso seperti aplikasi operasional tabungan investa cendekia, pengelolaan dana tabungan investa cendekia dan lain-lain.

\section{F. Teknik Analisis Data}

Penelitian dilakukan dengana analisis kualitatif yaitu prosedur penelitian yang menghasilkan kata-kata tertulis atau lisan dari orang-orang dan keadaan yang diamati. ${ }^{23}$ Metode analisis yang digunakan adalah dengan menggunakan pendekatan kualitatif deskriptif yaitu dengan cara memaparkan informasi-informasi faktual yang diperoleh dari bank Syariah mandiri KCP Katamso, yang berhubungan dengan metode penentuan bagi hasil pada produk investa cendekia dengan tujuan membuat deskripsi, gambaran atau lukisan secara sistematis, faktual dan akurat mengenai fakta-fakta, sifatsifat, serta fenomena yang diteliti. ${ }^{24}$

Karya), p. 4.

${ }^{23}$ Lexy J. Moleong (1997), Metode Penelitian Kualitatif, (Bandung: PT. Remaja Rosda

${ }^{24}$ Moh. Nazir (2003), Metode Penelitian (Jakarta: PT. Ghalia Indonesia). 


\section{ANALISIS DAN PEMBAHASAN}

\section{A. Aplikasi Akad Produk Tabungan Investa Cendekia BSM ${ }^{25}$}

Tabungan investa cendekia BSM adalah sebuah produk investasi yang dikhususkan untuk rencana pendidikan buah hati dengan fasilitas autodebet dari rekening utama BSM, dimana nasabah tidak lagi harus repot ke bank untuk membayar setoran bulanannya. Setoran perbulan yang fleksibel mulai dari Rp100.000 sampai Rp4.000.000 perbulan memungkinkan nasabah untuk memberikan pendidikan yang lebih baik untuk buah hati nasabah dimasa depan. Jangka waktu mulai 1 tahun sampai 20 tahun memungkinkan nasabah memberikan pendidikan sampai tingkat perguruan tinggi, tabungan ini pun dilengkapi dengan asuransi jiwa dimana preminya mulai dari $2,5 \%-6,5 \%$ yang langsung dipotong dari setoran perbulan nasabah, sehingga nasabah tidak perlu repot menghitung berapa preminya perbulan yang nasabah harus bayarkan.Manfaat perlindungan asuransi ini mencapai $327 x$ setoran perbulan. Akad yang diterapkan pada produk tabungan investa cendekia BSM adalah Mudharabah Muthlaqah, dimana penabung akan mendapatkan bagi hasil sesuai dengan nisbah yang telah disepakati di awal pembukaan tabungan.

\section{B. Mekanisme Penentuan Nisbah Bagi Hasil Tabungan Investa Cendekia BSM ${ }^{26}$}

Prinsip penentuan nisbah bagi hasil produk tabungan investa cendekia BSM sama dengan produk-produk perbankan syariah yang lain. Penentuan besarnya rasio bagi hasil dibuat pada waktu akad dengan berpedoman pada kemungkinan untung rugi.Besarnya rasio bagi hasil berdasarkan pada jumlah keuntungan yang diperoleh.Bagi hasil bergantung pada keuntungan proyek yang dijalankan. Bila usaha merugi, kerugian akan ditanggung bersama oleh kedua belah pihak. Dan jumlah pembagian laba meningkat sesuai dengan meningkatnya jumlah pendapatan.Dengan perhitungan sebagai berikut:

\section{Bagi Hasil$$
=\frac{\text { Total Pendapatan Bank Syariah - Seluruh Biaya Operasional Bank Syariah }}{\text { Seluruh Nasabah }}
$$

Adapun porsi tiap-tiap nasabah disesuaikan dengan porsi nisbah dan uang yang diinvestasikan untuk bagi hasil. Nasabah Tabungan Investa Cendekia BSM akan mendapat bagi hasil berdasarkan saldo rata-rata tiap bulan. Yaitu dengan nisbah bagi hasil Tabungan Investa Cendekia 52\% (nasabah) : 48\% (BSM). Bagi hasil TIC diperhitungkan berdasarkan saldo rata-rata harian dan akan dibukukan ke rekening TIC nasabah.

${ }^{25}$ wawancara dengan supervisor BSM KCP katamso (Bp. M. Heriyanto) pada tanggal 16 Januari 2012.

${ }^{26}$ wawancara dengan supervisor BSM KCP katamso (Bp. M. Heriyanto), pada tanggal 16 Januari 2012. 


\section{Mekanisme Operasional Bagi Hasil Produk Investa Cendekia BSM. ${ }^{27}$}

Tabungan Investa Cendekia merupakan perniagaan yang dilakukan pihak bank atas dasar suka sama suka dan saling rela. Bank sebagai mudharib mempunyai kewajiban untuk memutarkan harta dari nasabah dan pihak nasabah harus rela memberikan hartanya untuk diputarkan pihak bank. Adapun prosedur pembukaan Tabungan Investa Cendekia dijelaskan dalam bentuk bagan berikut berdasarkan data yang diperoleh selama observasi.

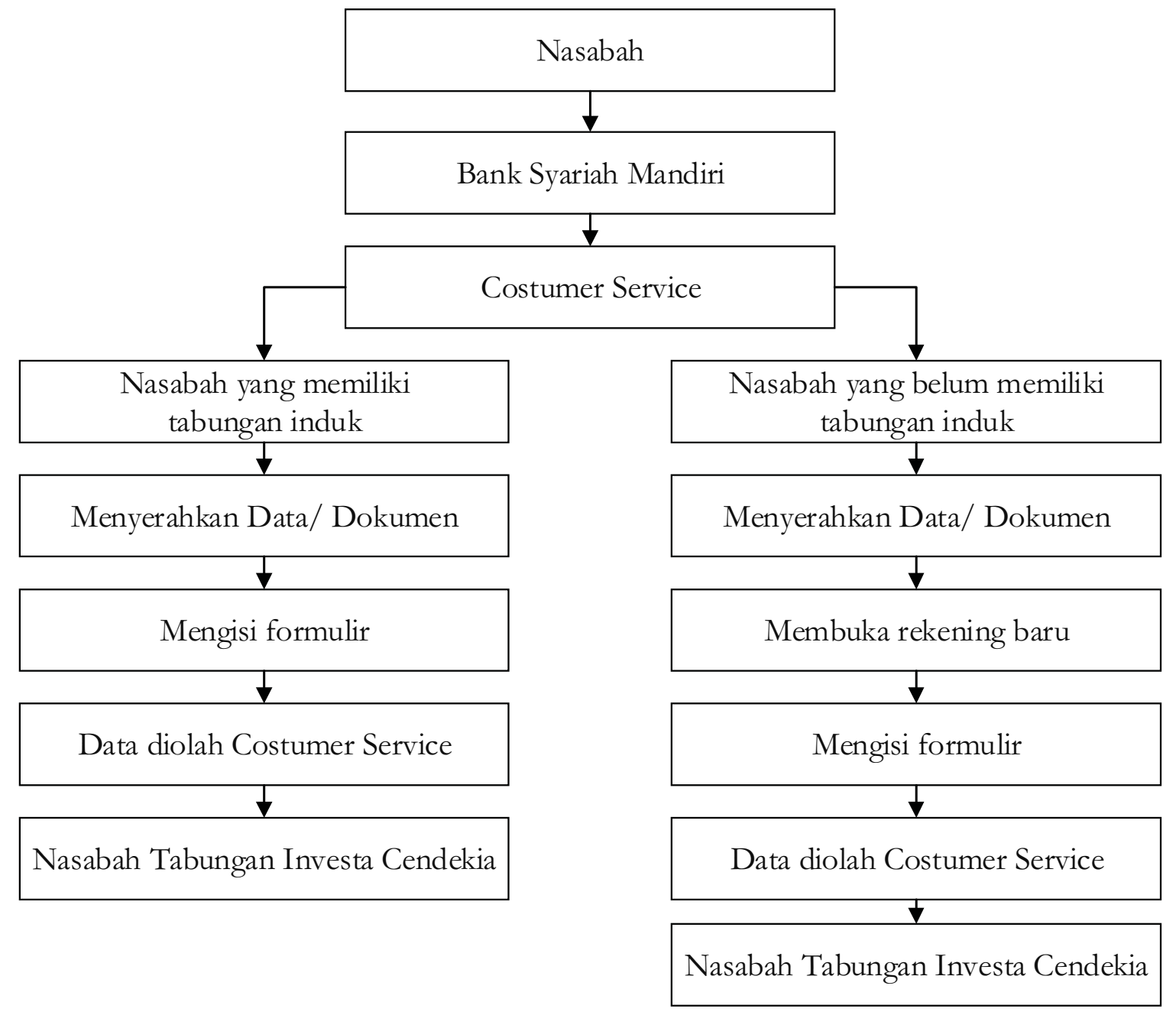

\section{Bagan 2 Prosedur Pembukaan Tabungan Investa Cendekia}

Sumber: data primer, hasil observasi

Tabungan Investa Cendekia (TIC) BSM merupakan produk yang diciptakan oleh Bank Syariah Mandiri yang memberikan kemudahan bagi para orang tua dalam hal perencanaan keuangan masa depan khususnya di bidang pendidikan putra/ putrinya. Hal tersebut berupa tabungan berjangka untuk keperluan uang pendidikan dengan jumlah setoran bulanan tetap yang didebet langsung dari rekening induk nasabah TIC dengan prinsip bagi hasil mudharabah muthlaqah. Keunggulan dari produk TIC ini

${ }^{27}$ Wawancara dengan Customer Servise Bank Syariah Mandiri KCP Katamso, Sdri. Chintya Nosa, pada tanggal 21 Januari 2012. 
adalah adanya fitur tambahan berupa perlindungan asuransi jiwa yang secara otomatis diperoleh nasabah TIC tanpa adanya pemeriksaan kesehatan. Produk TIC BSM ini sangat membantu para orang tua dalam hal merencanakan uang pendidikan anaknya di masa yang akan datang, karena setoran tetap perbulannya cukup ringan yaitu minimal Rp 100.000 sampai dengan Rp 4.000.000, nasabah TIC dapat memilih setoran tetap bulanan sesuai dengan kemampuan masing-masing dan ketika nasabah memiliki kelebihan dana dapat disetorkan ke rekening TIC tanpa menghapus kewajiban membayar setoran bulanan. Disamping itu nasabah TIC BSM juga secara otomatis mendapatkan perlindungan asuransi jiwa tanpa pemeriksaan kesehatan dan premi bulanannya pun sangat kecil dibanding dengan premi asuransi pendidikan pada umumnya.

Pada pembahasan ini analisis dilakukan untuk melihat apakah implementasi akad pada produk tabungan investa cendekia di BSM KCP Katamso Yogyakarta yang berdasarkan prinsip syariah berupa mudharabah muthlaqah telah sesuai dengan pandangan hukum ekonomi islam atau fiqh dan Fatwa Dewan Syariah Nasional terkait transaksi TIC, begitu juga mekanisme operasionalnya. Analisis ini difokuskan pada tujuan tabungan investasi cendekia (TIC) BSM, mekanisme TIC, keuntungan TIC, bagi hasil TIC, serta penerapan asuransi jiwa yang merupakan fitur tambahan produk TIC di Bank Syariah mandiri KCP Katamso Yogyakarta.

\section{Analisis Implementasi Akad pada Produk Investa Cendekia (TIC) di Bank Syariah Mandiri KCP Katamso Yogyakarta.}

Akad yang diterapkan pada produk tabungan investa cendekia BSM adalah Mudharabah Muthlaqah, seperti yang telah tertera pada form aplikasi pembukaan rekening tabungan investa cendekia BSM, di dalam form aplikasi tersebut penabung telah mengikrarkan untukmenginvestasikan dananya melalui Bank Syariah Mandiri dan BSM akan berbagi hasil atas nama penabung yang diinvestasikan dengan perbandingan bagi hasil sesuai nisbah yang telah disepakati di awal pembukaan tabungan berdasarkan saldo rata-rata tiap bulan. adapun nisbah bagi hasil Tabungan Investa Cendekia 52\% (nasabah) : 48\% (BSM). Bagi hasil TIC diperhitungkan berdasarkan saldo rata-rata harian dan bagi hasil akan diberikan kepada penabung setiap tanggal 1 bulan berikutnya setelah diperoleh hasil investasi pada bulan berjalan. Bank dapat merubah dan menetapkan bagi hasil yang baru yang akan diinformasikan melalui papan pengumuman di counter cabang bank dan akan berlaku pada awal bulan berikutnya, jika dalam 10 hari kalender setoran pengumuman tersebut dikeluarkan penabung tidak mengajukan keberatan secara tertulis disertai pembatalan keikutsertaannya pada program tabungan investa cendekia BSM, maka penabung dianggap dapat menyetujui perubahan besaran bagi hasil tersebut.

Adapun operasional produk TIC sesuai dengan maksud dari akad mudharabah muthlaqah (bagi hasil mutlak), yaitu pemilik modal memberikan dananya kepada pelaksana usaha yang dalam pembahasanini adalah Bank Syariah Mandiri, dimana tidak 
ada pembatasan jenis usaha, tempatnya, waktunya dan orang yang diajak untuk bekerja sama. Dalam syirkah seperti ini, pelaksana boleh mendayagunakan modal yang menurut pandangannya akan mendatangkan kemaslahatan dan sesuai dengan keahlian para pengusaha. ${ }^{28} \mathrm{Akad}$ mudharabah muthlaqah dapat diterapkan untuk produk tabungan dan deposito. Bank wajib memberitahukan kepada pemilik dana mengenai nisbah dan tata cara pemberitahuan keuntungan begitu juga dengan pembagian keuntungan dan risiko yang dapat ditimbulkan dari penyimpanan dana. Apabila telah tercapai kesepakatan maka hal tersebut harus dicantumkan dalam akad.Untuk tabungan mudharabah, bank dapat memberikan buku tabungan sebagai bukti penyimpanan. ${ }^{29}$

Dalam fatwa No: 02/ DSN-MUI/ IV/2000 tentang tabungan, juga telah dijelaskan bahwa tabungan yang tidak dibenarkan secara syariah adalah tabungan yang berdasarkan perhitungan bunga. Dan tabungan yang dibenarkan oleh syariah adalah tabungan yang berdasarkan prinsip Mudharabah dan Wadi'ah. ${ }^{30}$ Dalam transaksi ini nasabah bertindak sebagai shahibul maal atau pemilik dana, dan bank bertindak sebagai mudharib atau pengelola dana. Dalam kapasitasnya sebagai mudharib, bank dapat melakukan berbagai macam usaha yang tidak bertentangan dengan prinsip syariah dan mengembangkannya, termasuk di dalamnya mudharabah dengan pihak lain. ${ }^{31}$

\section{Analisis Penerapan Bagi Hasil Produk Investa Cendekia Syariah Mandiri}

Berdasarkan data yang peneliti terima dari customer service Bank Syariah Mandiri KCP Katamso Yogyakarta, perhitungan bagi hasil pada tabungan investa cendekia mempunyai ketentuan sebagai berikut: ${ }^{32}$

a. Bagi hasil TIC dihitung berdasarkan saldo rata-rata harian dan akan dibukukan ke rekening TIC

b. Bank dapat merubah dan menetapkan bagi hasil baru yang akan diinformasikan melalui papan pengumuman di counter cabang bank yang akan berlaku pada awal bulan berikutnya.

Berkaitan dengan nisbah bagi hasil antara nasabah dan bank, Bapak Heriyanto selaku supervisor Bank Syariah Mandiri KCP Katamso, menjelaskan dalam wawancara pada tanggal 16 Januari 2012, bahwa TIC memiliki sifat mengendap, dalam artian TIC memiliki jangka waktu menabung yang lebih panjang dibanding tabungan lain yaitu 1 tahun sampai dengan 20 tahun (sesuai dengan kehendak nasabah) dan tidak boleh

${ }^{28}$ Abdullah bin Muhammad Ath-Thayyar,et.al. (2004), Ensiklopedi Fiqih Muamalah dalam Pandangan 4 Madzhab, Cetakan. 1 (Yogyakarta: Maktabah Al-Hanif), p. 288.

${ }^{29}$ Heri Sudrsono (2008), Bank dan Lembaga Keuangan Syariah, p. 66.

${ }^{30}$ Mardani (2001), Ayat-Ayat dan Hadis Ekonomi Syariah, Cet. 1 (Jakarta: Rajawali Press), p. 88.

${ }^{31}$ Zainuddin Ali (2008), Hukum Perbankan Syariah, Cet. 1 (Jakarta: Sinar Grafika), p. 244.

32 Wawancara dengan Customer Service BSM KCP Katamso, Sdri. Chintya Nosa, pada tanggal 21 Januari 2012. 
diambil sewaktu-waktu, maka nisbah bagi hasil untuk nasabah TIC lebih besar dibandingkan dengan bagi hasil untuk nasabah tabungan lain, yaitu 52\% hampir setara dengan bagi hasil deposito.

Keterangan di atas sesuai dengan Ketentuan hukum dalam Fatwa DSN MUI No. 15/DSN-MUI/IX/2000 Tentang Prinsip Distribusi Hasil Usaha dalam Lembaga Keuangan Syari'ah adalah sebagai berikut:

> Pada dasarnya, LKS boleh menggunakan prinsip Bagi Hasil (Net Revenue Sharing) maupun Bagi Untung (Profit Sharing) dalam pembagian hasil usaha dengan mitra (nasabah)-nya.

$>$ Dilihat dari segi kemaslahatan (al-ashlah), pembagian hasil usaha sebaiknya digunakan prinsip Bagi Hasil (Net Revenue Sharing).

$>$ Penetapan prinsip pembagian hasil usaha yang dipilih harus disepakati dalam akad.

\section{Analisis Sistem Opersional Produk Investa Cendekia BSM \\ a. Sistem Operasional Tabungan Investa Cendekia}

Tabungan Investa Cendekia merupakan perniagaan yang dilakukan pihak bank atas dasar suka sama suka dan saling rela. Bank sebagai mudharib mempunyai kewajiban untuk memutarkan harta dari nasabah dan pihak nasabah harus rela memberikan hartanya untuk diputarkan pihak bank. Allah SWT juga telah memerintahkan kepada hambaNya agar menabung untuk masa depan dan mengantisipasi hal-hal yang tidak diinginkan.Adapun Akad yang diterapkan pada produk tabungan investa cendekia BSM adalah Mudharabah Muthlaqah, dimana penabung akan mendapatkan bagi hasil sesuai nisbah yang telah disepakati di awal pembukaan tabungan berdasarkan saldo rata-rata tiap bulan. Hal ini sesuai dengan fatwa DSN-MUI No 2 Tahun 2000 tentang Tabungan, dalam fatwa tersebut dijelaskan bahwa tabungan yang dibenarkan adalah tabungan yang berdasarkan prinsip mudharabah dan wadi'ah.

\section{b. Sistem Operasional Penerapan Asuransi Jiwa Tabungan Investa Cendekia BSM}

Berdasarkan data berupa dokumen dari Bank Syariah Mandiri, Tabungan Investa Cendekia merupakan tabungan pendidikan yang bekerjasama dengan perusahaan asuransi syariah yaitu Takaful, dimana ketika seorang nasabah menabung di TIC maka nasabah tersebut akan langsung terproteksi asuransi jiwa tanpa disertai cek kesehatan sebelumnya. Penambahan fitur pada TIC berupa asuransi jiwa ini sesuai maksud dari ayat Q. S. Yusuf (12) : 78 yang menegaskan agar diambil salah satu saudara Yusuf as untuk menggantikan posisinya. Kondisi demikian termasuk dalam kafalah (jaminan) jiwa. Mayoritas fuqahâ' dari kalangan Hanafiyyah, Malikiyyah, Syafi'iyyah dan Hanbaliah berpendapat bahwa kafalah (jaminan) jiwa hukumnya boleh. ${ }^{33}$ Fatwa DSNMUI No. 21 Tahun 2001 tentang Pedoman Asuransi Syariah juga menjelaskan bahwa asuransi (Ta'min, Takaful atau Tadhamun) adalah usaha tolong menolong di antara

\footnotetext{
${ }^{33}$ Abdullah bin Muhammad ath-Thayyar dkk, Ensiklopedi Fiqih Muammalah, hal. 192.
} 
sejumlah orang/pihak melalui investasi dalam bentuk aset dan/ atau tabarru yang memberikan pola pengembalian untuk menghadapi risiko tertentu melalui akad (perikatan) yang sesuai dengan syri'ah. Yang dimaksud dengan syari'ah di sini adalah tidak mengandung gharar (penipuan), maysir (perjudian), riba, zhulm (penganiayaan), risywah (suap), barang haram dan maksiat.

\section{KESIMPULAN}

Berdasarkan hasil penelitian dan pembahasan di atas, maka dapat ditarik kesimpulan bahwa Tabungan Investa Cendekia BSM merupakan tabungan berjangka untuk keperluan pendidikan dengan jumlah setoran bulanan tetap dan dilengkapi dengan fitur tambahan berupa perlindungan asuransi jiwa bagi pemilik rekening. Akad yang diterapkan pada produk Tabungan Investa Cendekia adalah mudharabah muthlaqah, dimana nasabah bertindak sebagai shâhibul mâl (pemilik modal) dan bank sebagai mudhârib (pengelola). Dana yang telah berhasil dihimpun dari Tabungan Investa Cendekia tersebut didayagunakan oleh bank untuk memenuhi permohonan pembiayaan mudharabah atau ijarah. Hasil usaha dari bank tersebut akan dibagi hasilkan berdasarkan nisbah yang telah disepakati.

Nisbah bagi hasil yang telah ditentukan oleh Bank Syariah Mandiri untuk produk Tabungan Investa Cendekia adalah 52 : 48, yaitu 52\% untuk nasabah dan 48\% untuk bank. Bagi hasil TIC dihitung berdasarkan saldo rata-rata harian dan akan dibukukan ke rekening TIC. Bagi hasil TIC BSM lebih tinggi dibanding tabungan biasa, karena TIC BSM memiliki jangka waktu dimana nasabah tidak dapat menarik saldo sewaktuwaktu. Ketentuan nisbah bagi hasil tersebut diatas telah dicantumkan dalam akad pembukaan rekening sesuai dengan Fatwa DSN-MUI No. 02 Tahun 2000 tentang Tabungan, bahwa pembagian keuntungan harus dinyatakan dalam bentuk nisbah dan dituangkan dalam akad pembukaan rekening. Begitu juga mekanisme bagi hasil Tabungan Investa Cendekia telah sesuai dengan Fatwa DSN MUI No. 15/DSNMUI/IX/2000 Tentang Prinsip Distribusi Hasil Usaha dalam Lembaga Keuangan Syari'ah.

Pada umumnya mekanisme operasional produk Tabungan Investa Cendekia sudah sesuai dengan prinsip-prinsip syariah, seperti yang telah dituangkan dalam Fatwa DSN-MUI No. 02 Tahun 2000 tentang Tabungan dan Fatwa DSN MUI No. 15/DSN-MUI/IX/2000 Tentang Prinsip Distribusi Hasil Usaha dalam Lembaga Keuangan Syari'ah. Dari segi penerapan akad, penentuan nisbah bagi hasil, pelaksanaan akad pembukaan rekening TIC BSM, pendayagunaan dana yang berhasil dihimpun dari nasabah TIC BSM, sampai dengan proses penutupan rekening pada saat jatuh tempo. Keunggulan dari Tabungan Investa cendekia adalah adanya perlindungan asuransi jiwa bagi nasabah pemilik rekening TIC BSM yang secara otomatis diperoleh nasabah tanpa pemeriksaan kesehatan, hal ini yang membedakan TIC BSM dengan produk tabungan lain. Klaim dapat diajukan apabila nasabah pemilik rekening TIC BSM mengalami kecelakaan sehingga mengakibatkan cacat tetap dan 
Retno Intansari Rahmawati: Analisis Metode Bagi Hasil...

meninggal dunia akibat sakit atau kecelakaan. Klaim diberikan kepada penerima manfaat asuransi yaitu putra/ putri nasabah TIC BSM. Hanya saja kelemahan dari Tabungan Investa Cendekia adalah proses klaim yang harus menunggu lama karena berhubungan dengan dua institusi berbeda yaitu Bank Syariah Mandiri dan perusahaan asuransi Takaful syariah, namun apabila nasabah telah melengkapi segala persyaratan administrasi hal tersebut dapat diantisipasi.

\section{DAFTAR PUSTAKA}

Ali, Zainuddin (2008). Hukum Perbankan Syariah. Jakarta: Sinar Grafika. Antonio, M. Syafi'i, et.al. (2008).Bank Syari'ah.Yogyakarta: Ekonisia.

Ath-Thayyar, Abdullah bin Muhammad,et.al.(2004). Ensiklopedi Fiqih Muamalah dalam Pandangan 4 Madzhab. Yogyakarta: Maktabah Al-Hanif.

Aziz, Abdul (2010).Manajemen Investasi Syariah, Cet.I. Bandung: ALFABETA.

Bank Indonesia (2009). "Mari Berbagi Hasil Bersama iB". Artikel edukasi perbankan diakses

darihttp://www.bi.go.id/web/id/Perbankan/Edukasi+Perbankan/Mari Berbagi H asil.htmpada 1 November 2011

(2009). "Menghitung Bagi Hasil iB”. Artikel edukasi perbankan diakses

dari

http://www.bi.go.id/web/id/Perbankan/Edukasi+Perbankan/Menghitung Bagi H asil iB.htmpada 1 November 2011.

Fadhila, Dewi Rohma. (2004). "Pengaruh Tingkat Bagi Hasil Dan Suku Bunga Terhadap Simpanan Mudharabah (Studi Kasus Bank Syariah Mandiri) Periode Januari 2001-Juni 2003", Skripsi Fakultas Ekonomi Universitas Islam Indonesia. Tidak diterbitkan.

Fatahullah. (2008). "Implementasi Prinsip Bagi Hasil dan Risiko di Perbankan Syariah (Studi di Perbankan Syariah Cabang Mataram)". Tesis Program Magister Ilmu Hukum Universitas Diponegoro Semarang. Tidak diterbitkan.

Fauziyah, Umi. (2006). "Analisis Metode Perhitungan Bagi Hasil pada Pembiayaan Mudharabah Berdasarkan Fatwa Dewan Syariah Nasional (DSN) di BMT KHONSA Cilacap". Skripsi STAIN Surakarta. Tidak diterbitkan.

http://netsains.com/2011/09/ironi-dunia-pendidikan/diakses pada 14 februari 2012. http://www.syariahmandiri.co.id/category/info-perusahaan/profil-perusahaandiakses

pada 3 Oktober 2011.

http://zonaekis.com/pertumbuhan-perbankan-syariah-belum-selesaikan-masalahekonomidiakses pada 3 Oktober 2011.

Karim,Adiwarman A. (2003)Bank Islam Analisis Fiqih dan Keuangan, Cet.1. Jakarta: IIIT Indonesia.

Raja Grafindo Persada.

Mardani (2001).Ayat-Ayat dan Hadis Ekonomi Syariah. Jakarta: Rajawali Press. 
Retno Intansari Rahmawati: Analisis Metode Bagi Hasil...

Moleong, Lexy J.(1997). Metode Penelitian Kualitatif.Bandung: PT. Remaja Rosda Karya.

Muhammad (2001).Tehnik Perhitungan Bagi Hasil di Bank Syariah. Yogyakarta: UII Press.

Muhammad (2006).Teknik Perhitungan Bagi Hasil dan Profit Margin pada Bank Syariah, Cet. 3. Yogyakarta: UII Press.

Muthahhari, Murtadha (1995).Pandangan Islam Tentang Asuransi dan Riba, (Bandung: Pustaka Hidayah).

Nazir, Moh. (2003).Metode Penelitian.Jakarta: PT. Ghalia Indonesia.

Sendra, Ketut (2007). Bancassurance = Bank + Asuransi, Cet. 1. Jakarta: PPM.

Sudarsono, Heri (2008), Bank dan Lembaga Keuangan Syariah: Deskripsi dan Ilustrasi, Cet. I,(Yogyakarta: Ekonisia, 2008).

Supardi (2005).Metodologi Penelitian Ekonomi dan Bisnis. Yogyakarta: UII Press.

Wawancara dengan Customer Servise Bank Syariah Mandiri KCP Katamso, Sdri. Chintya Nosa, pada tanggal 21 Januari 2012.

Wawancara dengan Supervisor BSM KCP Katamso,Bapak M. Heriyanto, pada tanggal 16 Januari 2012. 